\title{
Chapter 9 \\ Diaspora Policies, Consular Services and Social Protection for Indian Citizens Abroad
}

\author{
Daniel Naujoks
}

\subsection{Introduction}

India not only has the largest emigrant population in the world. The country also has a long history of establishing an institutional framework and a multi-faceted infrastructure for its diverse diaspora populations. In the past 40 years, a variety of institutions have been created, changed, discarded, and merged. Some mechanisms were ad hoc and temporary in nature, some were established in partnership with the private sector. The varying needs of India's heterogenous and vast diaspora and emigrant populations have led to a plethora of policy initiatives. Because of the political will to communicate about the adoption of proactive policies, on the one hand, and limited resources of a developing country, on the other, several policies exist more on paper or are limited to low-scale implementation.

This chapter provides a broad overview of existing initiatives, shedding light on specific policy designs to include and exclude different populations in India and abroad. Given limitations in space and scope, this chapter focuses on the current institutions with brief references to infrastructure that has recently been replaced. While the chapter puts an emphasis on the letter of the law, I attempt to provide information on the origins and implementation of policies, where possible. However, the dearth of in-depth analysis on the vast majority of India's initiatives provides challenges for establishing clear evidence on drivers and rationales for policy processes.

The chapter shows that India has established a set of policies for various diaspora populations that are largely separate from the rules and policies adopted for nationals at home. Thus, diaspora engagement policies, and especially policies aimed at fostering social protection of Indians abroad, are generally not integrated into

D. Naujoks $(\bowtie)$

Columbia University, New York City, NY, USA

e-mail: daniel.naujoks@columbia.edu 
national social protection policies. There is a clear distinction between diaspora policies that are geared towards the engagement of ethnic Indian populations whose forefathers have left Indian shores many generations ago, Indian communities in OECD countries - mostly US, Canada, Europe and Australia, and migrant workers going on temporary assignments to countries in the Persian Gulf. Protection policies are generally limited to Indian citizens and the majority of special programs are limited to temporary migrant workers in specified countries.

\subsection{Diaspora Characteristics and Home Country Engagement}

\subsubsection{The Indian Diaspora and its Relations with India}

Before outlining India's diaspora infrastructure, this chapter will briefly elaborate on different terms that have developed to describe people who trace their origin to modern-day India. Some of these terms are colloquially used, some have different meanings in official policies and legal documents, making it difficult to assign singular meanings and definitions. Policy and legal definitions are important to understand specific benefits, collected data, and official narratives.

The most common term used to describe diasporic Indians is Non-resident Indians, or NRIs. ${ }^{1}$ Originally deriving from a tax category, the term used to refer to Indian citizens living in India for less than 182 days each year. In this sense, it is often used to distinguish Indian citizens living abroad from those who have acquired a different citizenship, who are referred to as Persons of Indian Origin (PIOs). ${ }^{2}$ As an overarching category to include NRIs and PIOs, government documents and policies refer to the Indian diaspora, Overseas Indians, or its Hindi equivalent Pravasi Bharatiya (Naujoks 2018a). ${ }^{3}$

As seen through the policy eyes of the Indian political system, overseas Indians fall into three broad categories:

- NRI temporary workers, mostly in the Gulf Cooperation Council (GCC) countries;

- NRI and PIOs in the US, Canada, Australia and Europe;

\footnotetext{
${ }^{1}$ It may be added that from a sociological viewpoint, diasporic actors have been defined as all persons who originate from a certain country, self-identify with that country, and who maintain a meaningful cultural and social relationship with the country (Sheffer 2003; Naujoks 2013, 12).

${ }^{2}$ Others understand as PIOs only those born abroad ( $2+$ generation), though this review focuses on government policies and thus, adopts the official terminology.

${ }^{3}$ For more details on different legal definitions when it comes to specific economic rights, see Naujoks (2018a, 92).
} 
- PIOs in countries where large-scale emigration took places roughly 150 years ago (Mauritius, South Africa, Fiji, Malaysia, Singapore, etc.), often referred to as the "old diaspora" (Dubey 2011; Lal 2018). ${ }^{4}$

According to UN data on international migrants, India is the largest source country of emigrants. About 17.5 million persons born in India are now living abroad, followed by 12 million Mexican and 11 million Chinese emigrants (United Nations 2019). This number includes both first generation NRIs and PIOs, but not overseas Indians who were born abroad. The Indian government estimates that in the end of 2018, out of 31 million overseas Indians, 13 million were NRIs and 18 million PIOs (Fig. 9.1).

Note: Per definition, UN emigrants also encompass all first-generation emigrants who obtained citizenship in countries of destination, hence becoming PIOs. Second generation Indian citizens abroad are NRIs but - generally - not migrants, according to UN statistics.

Figure 9.2 illustrates the distribution of Indian emigrants across the major 15 countries of destination. These 15 countries collectively account for $95 \%$ of all Indian migrants in the world, excluding though the majority of persons of Indian origin. GCC countries host half of Indian migrants (51\%), which explains why the Indian policy framework has a strong emphasis on migrants to this part of the world. ${ }^{5}$

Note: This refers exclusively to Indian emigrants captured in UN data, not the broader definition of Overseas Indians (Fig. 9.1). The dotted line displays the cumulative share of the host countries in all Indian emigrants. Thus, the eight major host

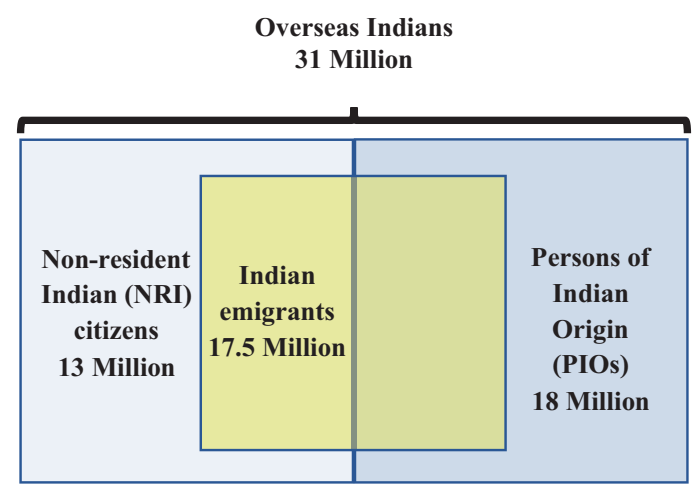

Fig. 9.1 Estimates for Overseas Indian populations (2018). (Source: Emigrant data: United Nations 2019; all other: Government of India 2018)

\footnotetext{
${ }^{4}$ For an overview of the Indian diaspora, see Dubey (2003); Raghuram et al. (2008); Sahoo, Baas, and Faist (2012); Mongia (2018).

${ }^{5}$ For more details on Indian migrants in the Persian Gulf, see Azhar (2016) and Rajan (2017).
} 


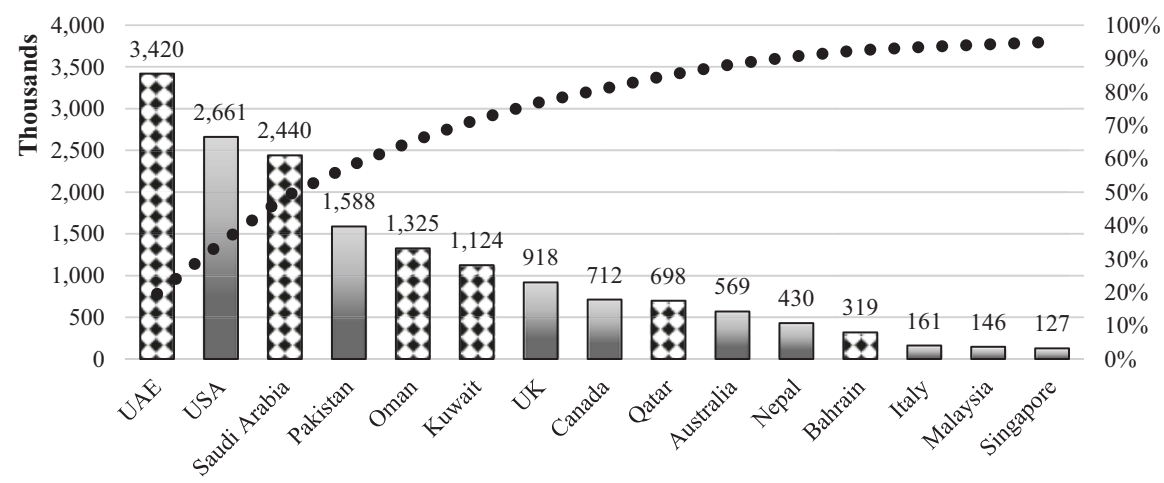

Fig. 9.2 Top 15 countries hosting Indian migrant populations (2019) (in thousands). (Source: Author's calculations, based on United Nations (2019) data)

countries collectively account for $80 \%$ of the entire Indian migrant population. Countries highlighted in a dotted pattern are West Asian countries.

As shown in Naujoks (2010), India's 'world view' of its diaspora has undergone a tremendous change, which in turn led to the adoption of a host of diaspora polices. Until the mid- to late 1990s, state institutions had a negative policy attitude, which can be paraphrased as follows:

The diaspora consists of three elements. First, those who left under colonial rule and who live in remote places like the Caribbean, Africa and Fiji, where they face significant social difficulties from the indigenous population, which is why India should not try to reach out to them. Second, highly-skilled migrants residing in industrialized Western countries, most of whom obtained free education in India and deserted India for their personal benefit, without caring about the progress of the country. Third, laborers who move temporarily to the Gulf countries and whose remittances are critical for their communities of origin. ${ }^{6}$

As the High-level Committee on the Indian Diaspora (2002:xi) concluded: "Barring some high profile names in the Information Technology and entertainment sectors abroad, the Diaspora has been largely out of public sight and awareness." This paradigm changed through a complex interplay of internal and external, objective and subjective factors ${ }^{7}$ to a perception that can be described as follows:

The enormous Indian diaspora covers all continents and over 100 countries. The diaspora in the Western countries is rich and makes India proud. Indians abroad are shining ambassadors of the great Indian civilization. They are remitting money ${ }^{8}$ and

\footnotetext{
${ }^{6}$ Whereas temporary migrants used to originate predominantly from India's Southern states, in recent years, the majority hail from Northern India.

${ }^{7}$ For a discussion of the factors, see Naujoks (2010).

${ }^{8}$ These narratives are supported by official statistics that show that in the past decade, each year India receives the largest amount of remittances in the world - in absolute terms. Slightly more than half of such funds originate from Gulf countries.
} 
are an asset to the country — they are a veritable 'brain bank' from which the country can make withdrawals.

The perception of the temporary Gulf migrants has not changed significantly, although there is a greater awareness to safeguard their rights and working conditions. This paradigm shift took place in many different strata of public life. The new views are expressed in statements from the political sphere, as in, "if there is an Empire today on which the sun truly cannot set, it is the empire of our minds, that of the children of Mother India, who live today in Asia, Africa, Australia, Europe, the Americas and, indeed, on the icy reaches of Antarctica" or the political party BJP, which led the ruling government coalition from 1998-2004, during which several new diaspora policies were established, "believes that the growing achievements of the vast Indian diaspora are a matter of pride and a source of strength for India." Hegde $(2018,77)$ argues that the Indian establishment revised and institutionalized the relationship with India's influential diaspora spread across the world in an effort to redesign its global image as a serious economic player and technological powerhouse. This remarkable paradigm shift may be dubbed as 'from the invisible diaspora to the diaspora empire' and 'from the traitor tune to a pride paradigm' (Naujoks 2010). In the light of the newly perceived value overseas Indians bring to India, a large set of diaspora engagement policies have been adopted. ${ }^{9}$

\subsubsection{India's Diaspora Infrastructure}

India's government institutions are geared towards specific components of these three categories of overseas Indians laid out in the previous section. In 2004, India established a special Ministry of Overseas Indian Affairs (MOIA) that had different joint secretaries and divisions to cater to different categories of overseas Indians. Gamlen $(2014,2019)$ shows that diaspora-related government offices have spread rapidly in the past decades. Whereas in 1980, only a handful of countries had established such institutions, by 2014, over half of all states in the United Nations had one. However, in 2015, the government of Prime Minister Narendra Modi merged the MOIA with the Ministry of External Affairs (MEA), where the bulk of issues related to diaspora and NRI affairs are handled now at the ministerial level. ${ }^{10}$ Within the MEA, the diaspora infrastructure is housed in the Overseas Indian Affairs division that includes the Protector of Emigrants, which focuses on (mostly temporary and low-skilled) labor emigration. Until 2004, the Protector of Emigrants was

\footnotetext{
${ }^{9}$ Dubey (2003) and Kahali (2017) detail the development of India's paradigms on diaspora issues. Hegde and Sahoo (2018) provide a broad overview of key issues regarding Indian diaspora communities and their relationship with India.

${ }^{10}$ Some of the departments had merged already before the final merger was announced. For an evolution of diaspora policies and infrastructure in India, see Lum (2014).
} 
housed in the Ministry of Labor. ${ }^{11}$ Then it became an integral part of the newly created MOIA, before moving with the entire overseas Indian portfolio to the MEA in 2015. The Protector of Emigrants focuses on protecting less-skilled labor emigration to the Gulf region and elsewhere. The other sections of the MEA's overseas Indian division focus on the other two segments of India's diaspora population. The MEA overseas embassies and consulates in 160 countries, as well as honorary councils in an additional 36 countries that cater to the needs of India's overseas population.

The work by the MEA is flanked by several independent or semi-independent bodies. Especially, the India Centre for Migration (ICM) and the Indian Council for Cultural Relations (ICCR). The ICM is supposed to act as a government-controlled think tank that undertakes research and studies on migration of Indian workers for overseas employment and supports informed policy making (MEA 2019c). Lastly, the Indian Council for Cultural Relations (ICCR) under the auspices of the Ministry of External Affairs is India's primary agency to formulate and implement policies and programs relating to India's external cultural relations.

The MEA runs Indian Workers Resource Centres (IWRC) in the UAE, Saudi Arabia, and Malaysia. They provide $24 \times 7$ helpdesks for both intending migrants and overseas Indians and an electronic platform attends to queries in 11 Indian Languages. These centres abroad are integrated with five domestic Migrant Resource Centres (MRCs) based in Kochi, Hyderabad, Gurgaon, Lucknow, and Chennai. ${ }^{12}$

As India has a decentralized structure of federal governance, some of India's states also created institutional and regulatory frameworks for diaspora and migrant populations. At least the states of Gujarat, Kerala, and Punjab pursue particularly active policies relating to their expatriate population. ${ }^{13}$

Since 1998, the Gujarat government maintains a separate Department for NonResident Gujaratis under which an autonomous Gujarat State Non-Resident Gujaratis (NRGs) Foundation aims at promoting social, cultural and linguistic bonds among the global Gujarati family, exploring the possibility of how NRIs and NRGs can play a vital role in the development of the state and identifying the areas in which the government can be of assistance to NRIs and NRGs.

In Kerala, the Department of Non-resident Keralites' Affairs (NORKA) was established in 1996 and 6 years later, its field agency Norka-Roots. Also in 1996, the NRI Sabha (assembly), Punjab, was founded as a non-governmental organization whose primary object was to strengthen the ties between the Punjabi diaspora and the people and culture of their motherland, and to help with their grievances, especially those concerning properties issues. Despite its set-up as an NGO, the NRI Sabha is chaired by the state government's Commissioner for NRI Affairs. Its chief

\footnotetext{
${ }^{11}$ Mongia (2018) provides an interesting analysis of the origins of the protector of emigrants under British colonial rule and its role in the system of indentured labor.

${ }^{12}$ For more information, see MEA (2019d).

${ }^{13}$ In addition to these three states, an increasing number of states have established NRI departments that aim at providing information and build partnerships with regional emigrant, diaspora and returnee communities.
} 
patron is the Chief Minister of Punjab ex-officio, while its elected president has to be a former NRI, which includes foreign citizens of Indian origin. Furthermore in 2007, the Government of Punjab established a Department of NRI Affairs. In addition to the three states mentioned above, various other states have created Nonresident Indian (NRI) centres and cells to facilitate the relationship with overseas Indians and to address their problems.

\subsubsection{Key Diaspora Engagement Policies}

Over the past 20 years, Indian state institutions have established a wide spectrum of diaspora engagement, as well as labor migration policies and programmes.

\section{Participation and Representation}

While there is no specific consultative or representative mechanism between the central government and overseas Indians, since 2003, the Government has held a large diaspora conference - the Pravasi Bhartiya Divas, one of the objectives of which is to consult with the diaspora and emigrant workers. ${ }^{14}$ At the regional level, in the state of Punjab, the NRI Sabha is set-up as a consultative body that includes government officials, as well as elected NRIs.

Before 2010, with the exception of Indian diplomats and other limited categories, Indian citizens living abroad were not allowed to cast their vote in elections back home. However, a 2010 amendment of the Representation of the People Act allowed NRIs to be included into voter rolls. However, NRI voters needed to return physically to India on election day to cast their vote and could not use postal ballot, voting at voting stations abroad or other remote procedures. As expected, this leads to no significant NRI voter turnout. In the end of 2017, the Government introduced the Representation of People Act Amendment bill 2017 that would allow NRIs to avail themselves of proxy voting. However, the bill lapsed with the dissolution of the 16th Lok Sabha and has since then not been reintroduced. It is interesting to note that the major political parties have affiliate groups, namely the "Friends of the Bharatiya Janata Party (BJP)" and the "Overseas National Congress."

\section{Economic Policies}

Overseas Indians have long served as a textbook example for the positive relationship between migration and development in migrants' countries of origin (Hunger 2004; Kapur 2010; Naujoks 2013). For this reason, for the past 20 years, economic policies with regard to overseas Indians have long been a central area of government intervention.

As there are restrictions for both, foreign direct and portfolio investments, it is important to note that India has created a range of special rules and facilities for NRI

\footnotetext{
${ }^{14}$ In addition, Mani and Varadarajan (2008) observe several critical attempts of the government to foster a neoliberal and nationalist agenda. See Singh $(2018 \mathrm{a}, \mathrm{b})$ for a recent assessment of the convention.
} 
investors (Naujoks 2018a). ${ }^{15}$ Even though India receives the largest amount of remittances, in absolute numbers, there are no policies on remittances. ${ }^{16}$ However, India created special savings accounts for NRIs. In the 1970s, the government of India felt the need to stock up the country's foreign-exchange reserves. For this purpose, it authorized special deposit schemes for NRIs. From the 1990s onward, the policies kept in focus that a high volatility of such deposits could be detrimental to the country's economic stability, which is why it was sought to attract stable deposits. In order to increase the attractiveness of such schemes, accounts could be denominated in foreign or domestic currency. They also had a higher than normal interest rate and accounted for certain tax exemptions (Naujoks 2018a). While there are no financial incentives for overseas Indians to buy real estate, India has adopted legislation that allows non-resident Indians to purchase real estate. Whereas India's FDI policy does not allow any FDI into firms engaged in real estate, FDI can be allocated to build townships, housing, and infrastructure. However, while certain conditions apply to non-diaspora FDI-such as the minimum area to be developed or to invest at least USD five million within the first 6 months of the project-these restrictions do not apply to investment by NRIs (Naujoks 2018a).

In addition, when the Indian economy was in urgent need of foreign exchange India issued three foreign-currency diaspora bond schemes. In total, India received USD 11.3 billion in foreign exchange from the three schemes, which were launched in order to help the country over the balance of payment crisis in 1991, strengthen the country when it suffered from sanctions imposed by the U.S. and the World Bank in response to India's nuclear tests in 1998 and smoothen the effects of an adverse global economy in 2000 (Ketkar and Ratha 2010).

Indian transnational diaspora organizations have been involved in promoting social and economic development in India (Agarwala 2018). For this reason, the Indian government seeks their contributions and offers organizations to register on a voluntary basis with Indian missions. However, given India's mistrust of any foreign contributions, diaspora organizations' engagement in India is highly regulated by the Foreign Contribution Regulation Act, $1976 \cdot{ }^{17}$ It channels charitable contributions from NRIs into local development projects that are suggested and implemented by state governments. Furthermore, India signed double taxation agreements with more than 130 countries.

\footnotetext{
${ }^{15}$ Only registered foreign portfolio investors, foreign institutional investors, that is, entities established or incorporated outside India and that are registered in India, and NRIs can invest through a registered broker in the capital of Indian companies on recognized Indian Stock Exchanges. In addition, there are facilitations for NRI direct investments in the air transport industry and real estate, for investments in partnership firms since 2015, investments by NRIs made on a non-repatriable basis are at par with domestic investments made by Indian residents. For more details, see Naujoks (2018a).

${ }^{16}$ For an introduction to money flows, gender and family among Indian migrants, see Singh (2018a, b) and Naujoks (2020b).

${ }^{17}$ Since 2008, the Government has been in the process of establishing the India Development Foundation of Overseas Indians (IDF-OI) that became operational in 2016 and that was finally closed in March 2018, as the foundation failed to attract meaningful contributions.
} 
In order to meet the diasporic demand for dual citizenship and within the state's economic engagement strategy with the diaspora, India created two special membership statuses. In 1999, the Indian government launched the Person of Indian Origin Card (PIO card), and in late 2003, legislation on the Overseas Citizenship of India (OCI) was adopted as another membership category and operationalized in $2005 .{ }^{18}$ In January 2015, the PIO card scheme was formally absorbed by OCI. By the end of 2017, almost 3.2 million persons of Indian origin had obtained OCI, about half in the U.S. and Canada, and 20 percent in the U.K.

\section{Cultural and Educational Policies}

The Indian Council for Cultural Relations (ICCR) is the main institution to promote Indian culture abroad. Whereas the ICCR deliberately provides cultural assistance to diasporic cultural needs, its endeavors are by no means limited to diasporic communities around the world but aim at fostering the cultural relations and mutual understanding between India and other countries. The ICCR runs 30 Indian Cultural Centers around the world and it funds chairs for Indian culture in other countries. Its website informs that in countries that have a sizeable ethnic Indian population, the centers focus on teaching Indian dance, music, languages and yoga, and organize national days and festivals. Further, since 2006, the Scholarship Programme for Diaspora Children grants scholarships of up to USD 4,000 per annum to 100-150 PIO and NRI students for undergraduate courses "in order to make higher education in India accessible to the children of overseas Indians and promote India as a centre for higher studies."

With the Tracing the Roots Programme, the Government aims at assisting persons of Indian origin in tracing their roots in India through a cooperation with private organizations. ${ }^{19}$ To ensure ongoing ties with the descendants of Indian migrants, so-called second-plus generation, the Know India Programme (KIP) involves a "three-week orientation programme for diaspora youth conducted with a view to promote awareness on different facets of life in India and the progress made by the country in various fields e.g. economic, industrial, education, science and technology, communication and information technology, culture" (MEA 2019b). The program is modeled on the Birthright Israel program (High-level Committee of the Indian Diaspora 2002, 339). However, whereas between 20,000 and 37,000 Jewish youths participate in the birthright program every year, the Indian program is a small-scale project. Since its inception in the end of 2003 until end 2017, India's KIP has brought a total of 1,533 diasporic youths to India, or an average of less than 100 youths every year. The small scale and low-level of implementation of these programmes illustrates that many of the programmes are first and foremost discursive tools (Naujoks 2013, 53).

\footnotetext{
${ }^{18}$ For an in-depth analysis of the genesis and impacts of the PIO card and OCI, see Naujoks (2013, 2020a).

${ }^{19}$ For the first years, the ministry had entered into a Memorandum of Understanding with the organization Indiroots, whereas in 2019, these assignments were handled by Singapore-based Alankit Assignments.
} 


\subsection{Diaspora Policies and Social Protection in India}

As one of the largest sending countries of labor migrants, many of which reside in countries where migrants have limited access to host country social protection schemes, the country has created a considerable number of policies and schemes to provide transnational protections for its citizens abroad. Many of these are restricted to Indian nationals residing in specific countries, most importantly the Gulf Cooperation Countries.

Welfare and social protection policies for overseas Indians include the now defunct Mahatma Gandhi Pravasi Suraksha Yojana (MGPSY) pension scheme for NRIs that will be discussed below, legal and financial assistance and the Pravasi Bhartiya Bima Yojana (PBBY), as well as the Indian Community Welfare Fund (ICWF).

Since 2009, the Indian Community Welfare Fund (ICWF) has assisted Indian nationals abroad in times of distress and emergency in the 'most deserving cases' on a 'means tested basis.' Beneficiaries do not have to repay the cost covered. It includes legal and financial assistance to Indian women who were abandoned, cheated, and/or abused by their NRI/PIO or foreign spouses; emergency medical care for accidents with serious life threatening injuries; the payment for small fines and penalties in respect of Indian nationals for minor offences/crimes, such as for "illegal stay in the host country where prima facie the worker is not at fault", and assistance for repatriation of nationals abroad. The stated target groups are "overseas Indian workers duped by unscrupulous intermediaries in the host countries, runaway house maids, those who become victim of accidents, deserted spouses of Overseas Indians or undocumented Overseas Indian workers in need of emergency assistance or any other Overseas Indian citizens who are in distress would be the main beneficiaries of the Fund." 20 The ICWF rules further allow consulates to pay for the transportation of mortal remains of deceased Indian national to India or local cremation/burial of deceased.

In the period 2009-2016, Indian consulates have provided support for 80,000 beneficiaries (India Center for Migration 2017). As Fig. 9.3 shows, two-thirds of these funds were used to provide funds for flights and accommodation. However, this also includes large scale evacuations of more than 6,200 Indians from Iraq, 3,600 from Libya, and most recently 6,700 from Yemen (Ibid.). ${ }^{21}$

Indian consulates have a large discretion as to whether the "beneficiary deserves to be assisted." Importantly, under ordinary circumstances, the funds are limited to Indian nationals who have entered the host country legally. The funds to provide such assistance have to be raised by Indian consulates by levying a Service Charge on Consular Services, as well as through voluntary contributions by the Indian community and budgetary support from the Government of India.

\footnotetext{
${ }^{20}$ For more details see, MEA (2019a).

${ }^{21}$ On India's emergency evacuations, see Xavier (2016).
} 
Fig. 9.3 Usage of Indian Community Welfare Fund (2009-2016). (Source: India Center for Migration 2017)

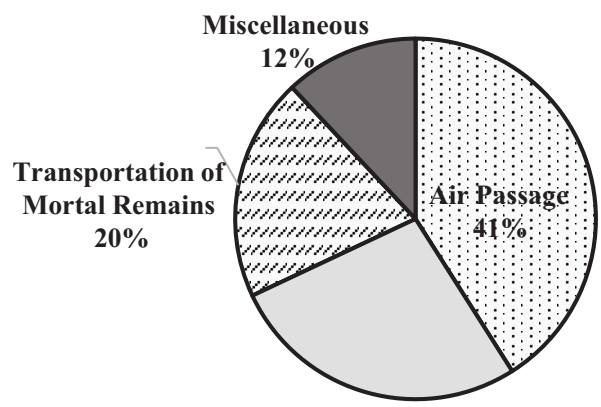

The Pravasi Bharatiya Bima Yojana (PBBY) is a mandatory insurance scheme aimed at safeguarding the interests of Indian emigrant workers falling under Emigration Check Required (ECR) category going for overseas employment to ECR countries. This applies to the 18 official ECR countries: Afghanistan, Bahrain, Indonesia, Iraq, Jordan, Kingdom of Saudi Arabia, Kuwait, Lebanon, Libya, Malaysia, Oman, Qatar, South Sudan, Sudan, Syria, Thailand, UAE, and Yemen, of which, at the time of writing, departures to Libya, Sudan, Syria, and Yemen have been suspended because of the security situation in these countries. The scheme, initially launched in 2003, has been amended in 2006, 2008, and 2017 with the overarching objective of strengthening the coverage of emigrant workers. At the regional level, under the Kerala Pravasi Welfare Board, the Non-Resident Keralites' Welfare Fund Act 2008 has developed some welfare schemes for the benefits of Non-Resident Keralites, such as several pension schemes. ${ }^{22}$

The following sub-sections will briefly elaborate on policies and programs that address policy issues related to unemployment, health care, pensions, family-related benefits, as well as resources for economic hardships.

\subsubsection{Unemployment}

While there are no specific policies and programs that address unemployment of Indian nationals abroad, the Indian government has created several skills upgrading initiatives that aim at increasing the employability of Indians abroad. Some of these programs are specific programs for prospective migrants, while others are part of general skill-upgrading endeavors for the Indian labor market. Specifically, the Pravasi Kaushal Vikas Yojana (PKVY) aims to enhance the skill sets of potential migrant workers and facilitate overseas employment opportunities. Launched at the 14th Pravasi Bhartiya Divas convention in 2017, it involves programmes of 2 weeks

\footnotetext{
${ }^{22}$ For more information, see http://pravasiwelfarefund.org
} 
to 1 month $^{23}$ that engage in capacity building in the areas of development of skills standards, curricula, learning material, assessment of standards, testing and certification on par with global standards. Initially, it focuses on sectors that are in demand in the ECR countries, including domestic workers, drivers and construction workers. ${ }^{24}$ This program is implemented by the MEA in collaboration with the Ministry of Skill Development and Entrepreneurship (MSDE). It is complemented by a compulsory pre-departure orientation (PDO), which prepares migrants for the journey to ECR countries. ${ }^{25}$ However, at the time of writing, the program was still in the development stage, though the Government of India has allocated funds for it in 2018. As of January 2018, India's National Skill Development Corporation (NSDC) enrolled 400 students in 13 India International Skill Centres in the pilot phase covering eight sectors, namely domestic workers, retail, hospitality, capital goods, healthcare, construction, automotive and security. ${ }^{26}$ Around 400 students have been enrolled in these centres.

At the sub-national level, there are no specific programs for unemployed emigrants. However, there is a regional pre-departure program and a skill enhancement program in the state of Kerala. Norka-Roots conducts one-day pre-departure training courses to overseas job aspirants to make them aware of the general job situations abroad and to impart essential information relating to visa, emigration rules, employment contract, customs regulations, and travel formalities etc. ${ }^{27}$ In addition, a program focuses on upgrading the skills of Keralites to meet the challenges in the employment market. ${ }^{28}$

\subsubsection{Health Care}

India's health care system is based on government health insurance schemes, as well as on private insurance schemes. The public insurance system includes government-owned companies, such as New India Assurance Co, Oriental Insurance Co, National Insurance Co and United Insurance India. NRIs could buy health insurance policies from such insurers for treatment in India, though there is no special provision or communication strategy on the part of the Government or these companies. For policies that allow accessing health care abroad, residential guidelines generally state that policies can be issued to Indian citizens residing in India alone. They explicitly stress that cover is not allowed to NRIs (and equally not to

\footnotetext{
${ }^{23}$ Ministry of External Affairs, mea.gov.in/press-releases.htm?...Pravasi+Kaushal+Vikas+Y ojana+PKVY

${ }^{24}$ For more details, see MEA (2019e) and India Migration Centre (2017, 7). However, no official announcements were made since the launch of the scheme in January 2017.

${ }^{25}$ See Rajan, Bhaskar, and Wadhawan (2017) for the content of this training.

${ }^{26} 50$ centres are slated to be further opened under this initiative (India Migration Centre 2017, 9).

${ }^{27}$ For more information, see Norka Roots (2019a).

${ }^{28}$ For more details, visit Norka Roots (2019b).
} 
foreign citizens living in India). ${ }^{29}$ NRIs are also not covered by India's Rashtriya Swasthya Bima Yojana (RSBY) health insurance scheme for the poor, though they might be eligible upon their return. However, the lack of any communication and outreach material in this regards highlights that these polices are not geared towards citizens abroad.

Apart from access to general health care systems, specific, though rather smallscale schemes have been adopted by the national and state governments to address select migrants' health concerns. The Indian Community Welfare Fund (ICWF) that was introduced in the beginning of this section can provide emergency medical care on a means tested basis to overseas Indians who are involved in an accident with serious life-threatening injuries, who have life-threatening medical conditions or suffer a serious disability. However, in the first 10 years of the fund's existence, fewer than 500 individuals have received support for emergency health care (India Migration Center 2017, 7). The Pravasi Bharatiya Bima Yojana insurance scheme for emigrant workers in the ECR category covers birth-related hospital costs of up to USD 350 in India, though to avail themselves of these maternity benefits abroad, all required documents need to be certified by the Indian Mission, thus creating a significant barrier to access said benefits.

In the Indian state of Kerala, the Kerala Pravasi Welfare Board can provide financial assistance under its medical treatment, accident-cum-death insurance scheme. Under this scheme, a member Non-Resident Keralite (NRK) who is afflicted with critical illness is eligible for obtaining a maximum financial assistance of INR 50,000 (approximately USD730) during the entire period of his or her membership. The Welfare Board can also engage with national insurance companies to provide such services. Furthermore, through the Santhwana Financial Assistance scheme for returned NRKs in distress, financial assistance is provided to NRKs or their dependent family members in case of medical treatment expenses, death assistance or the acquisition of artificial limbs, crutches, wheel chair or other aids to overcome physical disability.

\subsubsection{Pensions}

India's National Pension Scheme (NPS) is a government-sponsored contribution pension system. Whereas it was initially launched for government employees only, since 2009 it is open to all employees in India. In 2015, NRIs were allowed to obtain a unique Permanent Retirement Account Number (PRAN) and thus subscribe to the pension scheme. NRIs pay into the scheme either by inward remittance through normal banking channels or out of funds held in their special diaspora savings accounts. Importantly, this is only open to Indian citizens and migrants' NPS account will be closed if they acquire a different citizenship, thus forfeiting their

\footnotetext{
${ }^{29}$ See for example New India’s Global Mediclaim Policy (New India Assurance 2019).
} 
Indian citizenship. ${ }^{30}$ Consulates and the MEA provide online information on how to access the pension scheme for NRIs.

In 2012, the government had launched the Mahatma Gandhi Suraksha Pravasi Yojana (MGPSY), as a voluntary scheme to provide social security coverage to Indians in emigration check required (ECR) countries. However, the lack of sufficient subscribers led to abandoning the scheme in early 2017 (MEA 2019h).

In the state of Kerala, Non-Resident Keralites who continuously contribute to the Welfare Fund up to the age of 60, are eligible for a monthly pension of INR 2,000 (approximately USD 30) after the age of 60.

\subsubsection{Family-Related Benefits}

While the Indian government does not grant specific family-related benefits to its nationals abroad, consulates are tasked with keeping the registers of births and deaths for the district and to issue duly certified copies of entries in the registers. ${ }^{31}$

\subsubsection{Economic Hardship}

Countries often provide specific resources for economic hardships that their citizens abroad experience. Such measures consist of means-tested benefits that are conceived as the last resort of social protection, i.e. the ultimate "safety net" that aims to prevent extreme hardship and protect single persons and households from severe poverty (Vintila and Lafleur 2020). The Indian Community Welfare Fund (ICWF) that has been introduced above is meant to assist Indian nationals abroad in times of distress and emergency - though as discussed above on a discretionary basis. Under the ICWF, consulates can provide distressed nationals abroad with boarding and lodging in a budget category or in shelters run by the Indian mission or an NGO empanelled with the mission. It can also pay for air passage to India for stranded overseas Indian nationals, as well as legal assistance for Indian nationals abroad who have committed minor crimes, offences or have been falsely implicated by their employer and put in jails. The consulate can further provide legal and financial assistance to Indian women, who were abandoned, cheated, or abused by their NRI/ $\mathrm{PIO}$ or foreign spouses. It can also pay small fines and penalties in respect of Indian nationals for minor offences, such as for illegal stay in the host country where prima facie the worker is not at fault, and to enable release of Indian nationals from jail or a detention center. There are no regional policies or schemes to cover such resources.

\footnotetext{
${ }^{30}$ On dual citizenship in India, see Naujoks (2013). For more details, see MEA (2019g).

${ }^{31}$ Cf. Citizens (Registration at Indian Consulates) Rules 1956, in exercise of the powers conferred by Sections 18(1) \& 2(f) and 5(1)(b) of the Citizenship Act, 1955. For more details, see MEA (2019f).
} 


\subsection{Conclusions}

As the country with the world's largest emigrant population and a long history of international mobility, India has adopted a multi-faceted institutional and policy framework to govern migration and diaspora engagement. However, India is also a developing country with a large domestic population and severe development challenges at home. Almost 300 million people are considered poor by national poverty standards $^{32}$ and its per capita Gross Domestic Product of USD 7,000 places it between Angola and Uzbekistan. ${ }^{33}$ This means that India experiences significant budgetary limitations when it comes to establishing meaningful social and legal protection system and diaspora engagement strategies. While there is not an urgent need to spend scarce resources on skilled and highly skilled emigrants in the US, Canada, Australia, Europe or other parts of the world, social protection schemes focus on low-skilled Indian migrants. For this reason, it makes sense that policies focus on the emigrant populations that reside in countries in the Gulf region, which do not have strong social protection systems for their large immigrant populations (Rajan 2017). Other diaspora engagement strategies focus on more socially integrated and often economically richer diaspora communities. Thus, India's differentiated approach takes into account the various socio-spatial positionalities of specific Indian migrant and diaspora populations. ${ }^{34}$

Gamlen (2014) conceptualized three rationales for establishing diaspora engagement policies. States can attempt to tap into the potential they see from looking at resources in the diaspora; they can embrace diaspora populations as part of nationalistic strategies of nation-building or they can be prompted by international debates and governance discourses. All elements are present in India's engagement strategies. Délano and Gamlen $(2014,44)$ argue that much recent interest in state-diaspora relations is linked to a resurgence in optimism about the relationship between migration and development. This can be confirmed for the case of India's engagement. While the major drivers seem to be the wish to tap into remittances and overseas employment opportunities, India also exemplifies the growing infrastructure around governing migration and a management approach to temporary migration. This appears to be based on domestic political pressures, the conviction that human rights issues of Indian migrants abroad create problems for the Government of India, as well as the international discourse on the protection of migrant workers. ${ }^{35}$

\footnotetext{
${ }^{32}$ Based on the World Bank's “" "lower middle-income"” poverty line, 660 million people in India were living below this poverty line in 2015 and 176 million were living in extreme poverty (World Bank 2018).

${ }^{33} 2019$ Gross domestic product based on purchasing power parity (PPP) and current USD, according to World Bank's World Development Indicators.

${ }^{34}$ Koinova (2018) highlights the importance of diaspora actors' socio-spatial positionality, as their power deriving from linkages to homeland, host-land and a variety of other global contexts.

${ }^{35}$ While this observation is based on the author's long-stranding research on policy processes in India (see Naujoks 2010, 2013, 2018a), there are limitations to fully understand the black-box of what drives policies and how to meaningfully conduct a meaningful policy analysis of these issues.
} 
Often India's diaspora policies are rather small in scale, indicating that a major objective of the policies is to announce said policies at government sponsored diaspora meetings, rather than actually having a measurable impact on outcomes (Naujoks 2013, 53). This is reflected in the relatively low budget that is available for such programs and in many cases the low number of beneficiaries. ${ }^{36}$

Endeavors to integrate migrants into development strategies in their countries of origin and destination is part of the global agenda for sustainable development (Naujoks 2018b). The Sustainable Development Goals (SDGs) that form the core of the globally agreed-upon development roadmap stress the importance of implementing social protection measures for all, social protection policies to achieve greater equality, and achieving universal health coverage for all. ${ }^{37}$ Combined with the SDGs' call for well managed migration policies, ${ }^{38}$ India and other countries of emigration may expand the scope and quality of their programs targeting migrant workers and their families.

In May 2018, during the regional election in the state of Karnataka, only six nonresident voters participated in the process. ${ }^{39}$ During the 2019 general election, some 900 million voters were eligible to cast their vote in India. It is obvious that an additional ten million Indian voters from abroad would not be able to substantially alter the outcome of a national election. However, since Indians have to return home on election day to exercise their vote, very few have availed themselves of this possibility. While close to 100,000 NRIs had registered as voters, the Indian Election Commission reported that only 25,000 of them voted $-98 \%$ of which in Kerala and only $4 \%$ were women. ${ }^{40}$ As mentioned above, the previously introduced bill to allow proxy voting for NRIs has lapsed. It remains to be seen what reforms India will introduce to provide meaningful political participation for citizens residing abroad and whether more political power for NRIs will also lead to more comprehensive and extensive social policies for Indian nationals living outside of India.

\footnotetext{
${ }^{36}$ Kapur and Nangia (2015) show that India's general social welfare policies have focused more on specific social protection programs than on the expansion of basic public services. As one of the possible explanations, the authors suggest that this may be the case as such programs have a stronger 'visibility,' as they are observable outcomes, which is connected to the more limited nature of their stated goals.

${ }^{37}$ See SDG targets $1.3,3.8$, and 10.4 , respectively.

${ }^{38}$ See SDG target 10.7 .

${ }^{39}$ Times of India, "Pravasi peeve: Despite Election Commission drive, only 6 NRIs registered to vote,"

April 24, 2018, https://timesofindia.indiatimes.com/india/pravasi-peeve-despite-election-commission-drive-only-6-nris-registered-to-vote/articleshow/63890252.cms

${ }^{40}$ Economic Times, "25,000 of 1 lakh overseas Indians registered in e-rolls voted in LS polls: EC," October 20, 2019, https://economictimes.indiatimes.com/news/politics-and-nation/25000-of1-lakh-overseas-indians-registered-in-e-rolls-voted-in-ls-polls-ec/articleshow/71673081. $\mathrm{cms}$ ?from=mdr. In August 2017, only 24,000 NRIs had registered as voter with the Indian Election Commission and it is estimated that only 12,000 of them voted, see Economic Times, "Only 24,000 overseas Indians have registered as voters," August 13, 2017, https://economictimes.indiatimes.com/nri/nris-in-news/only-24000-overseas-indians-have-registered-as-voters/articleshow/60043359.cms
} 
Acknowledgements This chapter is part of the project "Migration and Transnational Social Protection in (Post)Crisis Europe (MiTSoPro)" that has received funding from the European Research Council (ERC) under the European Union's Horizon 2020 research and innovation programme (Grant agreement No. 680014). In addition to this chapter, readers can find a series of indicators comparing national social protection and diaspora policies across 40 countries on the following website: http://labos.ulg.ac.be/socialprotection/.

The author is indebted to Ajay Dubey, Ajaya K. Sahoo, and Jean-Michel Lafleur for insightful comments on an earlier draft of the chapter and to Ruchi Verma for valuable research assistance.

\section{References}

Agarwala, R. (2018). Transnational diaspora organizations and India's development. In R. S. Hegde \& A. K. Sahoo (Eds.), Routledge handbook of the Indian diaspora (pp. 104-116). Milton Park/ New York: Routledge.

Azhar, M. (2016). Indian migrant workers in GCC countries. Diaspora Studies, 9(2), 100-111. https://doi.org/10.1080/09739572.2016.1183890.

Délano, A., \& Gamlen, A. (2014). Comparing and theorizing state-diaspora relations. Political Geography, 41, 43-53.

Dubey, A. (Ed.). (2003). Indian diaspora: Global identity. New Delhi: Kalinga.

Dubey, A. (2011). India and the Indian diaspora. In D. Scott (Ed.), Handbook of India's international relations (pp. 255-264). London/New York: Routledge.

Gamlen, A. (2014). Diaspora institutions and diaspora governance. International Migration Review, 48(1 suppl), S180-S217.

Gamlen, A. (2019). Human geopolitics. States, emigrants, and the rise of diaspora institutions. Oxford: Oxford University Press.

Government of India. (2018). Population of overseas Indians (Compiled in December 2018). http://mea.gov.in/images/attach/NRIs-and-PIOs_1.pdf. Accessed on 17 Mar 2020.

Hegde, R. S. (2018). Renewing diasporic bonds and the global branding of India. In R. S. Hegde \& A. K. Sahoo (Eds.), Routledge handbook of the Indian diaspora (pp. 269-281). Milton Park/ New York: Routledge.

Hegde, R. S., \& Sahoo, A. K. (2018). Introduction. In idem (Ed.), Routledge handbook of the Indian diaspora (pp. 1-13). Milton Park/New York: Routledge.

High-level Committee on the Indian Diaspora. (2002). Report on the Indian diaspora. New Delhi: Ministry of External Affairs, Government of India.

Hunger, U. (2004). Indian IT-entrepreneurs in the US and India. An illustration of the "brain gain hypothesis". Journal of Comparative Policy-Analysis, 6(2), 99-109.

India Centre for Migration. (2017). Welfare and protection of Indians abroad. New Delhi: Ministry of External Affairs.

Kahali, A. (2017). Diaspora engagement: Need for paradigm shift - Indian perspective. Diaspora Studies, 10(1), 1-24. https://doi.org/10.1080/09739572.2016.1239432.

Kapur, D. (2010). Diaspora, development and democracy. The domestic impact of international migration from India. New Delhi: Oxford University Press.

Kapur, D., \& Nangia, P. (2015). Social protection in India: A welfare state sans public goods? India Review, 14(1), 73-90.

Ketkar, S., \& Ratha, D. (2010). Diaspora bonds: Tapping the diaspora during difficult times. Journal of International Commerce, Economics and Policy, 1(2), 251-263.

Koinova, M. (2018). Sending states and diaspora positionality in international relations. International Political Sociology, oly008. https://doi.org/10.1093/ips/oly008.

Lal, V. (2018). Indian servitude in the British empire. In R. S. Hegde \& A. K. Sahoo (Eds.), Routledge handbook of the Indian diaspora (pp. 17-27). Milton Park/New York: Routledge. 
Lum, K. (2014). Operationalising the highly-skilled diasporic transnational family: India and China's transnational governance strategies. Diaspora Studies, 8(1), 51-65.

Mani, B., \& Varadarajan, L. (2008). The largest gathering of the global Indian family: Neoliberalism, nationalism, and diaspora at Pravasi Bharatiya divas. Diaspora, 14(1), 45-74.

Ministry of External Affairs (MEA). (2019a). Indian Community Welfare Fund (ICWF). http:// www.mea.gov.in/icwf.htm, archived at http://www.webcitation.org/76yKrbDGK.

Ministry of External Affairs (MEA) (2019b). Tracing the Roots. https://mea.gov.in/tracing-theroots.htm, archived at http://www.webcitation.org/76yKN8kat.

Ministry of External Affairs (MEA) (2019c). India Centre for Migration. https://www.mea.gov.in/ icm.htm, archived at http://www.webcitation.org/76yL6Dtb5.

Ministry of External Affairs (MEA). (2019d). Overseas workers resource centre. https://www. mea.gov.in/owrc-and-pbsk.htm, http://www.webcitation.org/76yLVv45G.

Ministry of External Affairs (MEA). (2019e). Welfare and protection of Indians Abroad, New Dehli. http://www.mea.gov.in/images/Revised_ICM_Booklet_17032017.pdf http://www.webcitation.org/76yLsIK9h.

Ministry of External Affairs (MEA). (2019f). The Citizens (Registration at Indian Consulates) Rules 1956. http://www.mea.gov.in/Uploads/PublicationDocs/141_The-Citizens-Registrationat-Indian-Consulates-Rules-1956.pdf, http://www.webcitation.org/76yM7j3gb.

Ministry of External Affairs (MEA). (2019g). NPS for NRIs. http://www.mea.gov.in/images/pdf/ nps-for-nri.pdf, http://www.webcitation.org/76yMCeZZB.

Ministry of External Affairs (MEA). (2019h). Mahatma Gandhi Pravasi Suraksha Yojana. https:// www.mea.gov.in/mgpsy.htm, http://www.webcitation.org/76yMi1kcG.

Mongia, R. (2018). Indian migration and empire: A colonial genealogy of the modern state. Durham: Duke University Press.

Naujoks, D. (2010). India and its diaspora. Changing research and policy paradigms. In D. Thränhardt \& M. Bommes (Eds.), National paradigms of migration research (pp. 269-300). Göttingen: V\&R Unipress.

Naujoks, D. (2013). Migration, citizenship and development. Diasporic membership policies and overseas Indians in the United States. New Delhi: Oxford University Press.

Naujoks, D. (2018a). Paradigms, policies and patterns of Indian diaspora investments. In R. S. Hegde \& A. K. Sahoo (Eds.), Routledge handbook of the Indian diaspora (pp. 90-103). Milton Park/New York: Routledge.

Naujoks, D. (2018b). Achieving the migration-related sustainable development goals. In United Nations and International Organization for Migration. In 2017 Situation Report on International Migration. Migration in the Arab Region and the 2030 Agenda for Sustainable Development (pp. 73-122). Beirut: UN Economic and Social Commission for Western Asia.

Naujoks, D. (2020a). Atypical citizenship regimes: Comparing legal and political conceptualizations. Comparative Migration Studies, 8, 1. https://doi.org/10.1186/s40878-019-0156-0.

Naujoks, D. (2020b). From Passport to Pennies: Exploring the effects of dual citizenship on migrants' remittances. Remittance Review, 5(1), 55-82. https://doi.org/10.33182/rr.v5i1.899.

New India Assurance. (2019). New India's global mediclaim policy, www.newindia.co.in/ portal/ product/knowMore/HEALTH/NG, http://www.webcitation.org/76yNN8BCD.

Norka Roots. (2019a). Pre-departure orientation programme, http://www.norkaroots.net/ pdoprogramme.aspx, http://www.webcitation.org/76yMa3V1i.

Norka Roots. (2019b). Skill upgradation training. http://www.norkaroots.net/skillupgradation. htm, http://www.webcitation.org/76yMkdiiC.

Raghuram, P., Sahoo, A., Maharaj, B., \& Sangha, D. (Eds.). (2008). Tracing an Indian diaspora: Contexts, memories, representations. London/New Delhi: Sage.

Rajan, S. I. (Ed.). (2017). India migration report 2016. Gulf migration. New Delhi: Routledge.

Rajan, S. I., Bhaskar, T. L. S., \& Wadhawan, N. (2017). Pre-departure orientation training training of trainers (TOT) manual. New Delhi: International Organziation for Migration and India Center for Migration. 
Sahoo, A. K., Baas, M., \& Faist, T. (Eds.). (2012). Indian diaspora and transnationalism. Jaipur: Rawat Publications.

Sheffer, G. (2003). Diaspora politics: At home abroad. Cambridge: Cambridge University Press.

Singh, A. (2018a). The Pravasi Bharati Divas and India's diaspora outreach through the 'economy of affection': Rhetoric and realities. Diaspora Studies, 11(2), 89-201. https://doi.org/10.108 0/09739572.2017.139837.

Singh, S. (2018b). Money flows, gender and family among Indian migrants to Australia. In R. S. Hegde \& A. K. Sahoo (Eds.), Routledge handbook of the Indian diaspora (pp. 117-127). Milton Park/New York: Routledge.

United Nations. (2019). International migration report 2019. United Nations Department of Economic and Social Affairs, Population Division, New York.

Vintila, D. \& Lafleur, J-M. (2020). Migration and access to welfare in the EU: The interplay between residence and nationality. In J-M. Lafleur and D. Vintila (Eds.), Migration and social protection in Europe and beyond (Volume 1). Comparing Access to Welfare Entitlement (pp. to be added later). Cham: Springer.

World Bank. (2018). Poverty and equity brief: India. October 2018. Washington DC.

Xavier, C. (2016). Bringing the diaspora home: India's expatriate evacuation operations, Carnegie India paper. Washington, DC: Carnegie Endowment for International Peace.

Open Access This chapter is licensed under the terms of the Creative Commons Attribution 4.0 International License (http://creativecommons.org/licenses/by/4.0/), which permits use, sharing, adaptation, distribution and reproduction in any medium or format, as long as you give appropriate credit to the original author(s) and the source, provide a link to the Creative Commons license and indicate if changes were made.

The images or other third party material in this chapter are included in the chapter's Creative Commons license, unless indicated otherwise in a credit line to the material. If material is not included in the chapter's Creative Commons license and your intended use is not permitted by statutory regulation or exceeds the permitted use, you will need to obtain permission directly from the copyright holder. 